\title{
정규화된 수두손실률에 의한 방조제 구간별 차수상태 평가 The Estimation of Seepage Blocking State with the Normalized Hydraulic Head Loss Rate at Each Seepage Segment in Sea Dike Embankment
}

\author{
임성훈 ${ }^{*,+} \cdot$ 허건 $^{* *}$ \\ Eam, Sung Hoon · Heo, Gun
}

\section{Abstract}

In this study the process of normalizing hydraulic head loss rate was developed for the purpose of estimation of seepage blocking state at each seepage segment in sea dike embankment. Pore water pressure sensors were installed with some interval along seepage path, then the hydraulic head loss rate at each segment between pore water pressure sensors was calculated, and then the calculated hydraulic head loss rate was normalized based on seepage path length. The comparison of normalized hydraulic head loss rates showed that the cross section of sea dike embankment was homogeneous approximately and the width of cross section was long enough to blocking tide water.

Keywords: Hydraulic head loss rate; seepage; sea dike; pore water pressure; normalization

\section{I. 서 론}

해안가에 농경지를 조성하고 담수호를 개발하는 간척사업 에서 방조제의 구조적 안정성은 매우 중요하다. 가장 최근에 방조제가 완공되고 현재 방수제를 비롯한 내부 개발이 진행 중인 새만금간척사업은 심해간척사업이고 내부에 농경지 이 외에도 다양한 복합산업단지가 조성될 계획이므로 바닷물을 막는 방조제의 안정성이 더욱 중요하다. 이와 같이 붕괴시 재 앙을 초래할 수 있는 방조제를 계획 및 시공 단계에서부터 철 저하게 검토 및 관리를 하는 것도 중요하지만 완공된 이후에 신뢰성이 있는 방법으로 유지관리를 하는 것도 매우 중요하다.

Hanssen and Leijen (2008)은 총 연장 17,000 km에 달하 는 네덜란드의 방조구조물 (WDS, Water Defense Structure) 에 대해서 지난 한 세기 동안 여전히 전문가들이 육안관찰로 외형상의 변형 유무를 감시해오고 있으며 이러한 방법은 번 거롭기 때문에 관찰빈도가 일 년에 1 번 정도로 간헐적이고주 관적이며 정성적인 문제점이 있다고 하였다. 그래서 방조제 외형의 변형유무를 짧은 시간 간격으로 감시할 목적으로 제

* Major of Rural Construction Engineering, Kongju National University

** Rural Research Institute, Korea Rural Community Corporation

+ Corresponding author

Tel.: +82-41-330-1264 FAX: +82-41-330-1269

E-mail: geotechkor@kongju.ac.kr

Received: August 26, 2014

Revised: November 11, 2014

Accepted: November 12, 2014
체에 표지판을 설치하고 위성레이더 간섭계를 이용해서 표지 판의 이동을 밀리미터 단위까지 감시하는 방안을 제시하였다 (Eam and Heo, 2014). Closson, and Karaki (2014)는 요르단 사해 (Dead Sea)에 있는 제방의 안정성 감시를 위해서 인공위 성 합성개구레이더 (SAR)의 차분간섭영상을 이용해서 지반 의 변위를 계측한 사례를 제시하였다.

이상과 같이 방조제의 외형상의 이상 유무에 대한 감시를 통해서 방조제의 안정성을 관리하는 방법이 많이 이용되고 있다. 한편으로는 물리탐사기법을 방조제 제체 내부의 감시 에 적용하였다. Kim et al. (2013)은 방조제의 3 차원 전기비저 항 모니터링 자료의 분석을 수행하였으며, 제체의 차수상태 평가를 위해서 소형루프 전자탐사, 전기비저항탐사 및 탄성 파탐사 등을 수행한 사례 등과 방조제의 변위측정을 위해서 GPS 측량을 수행한 사례 등이 몇몇 학술발표회에서 소개되 었다.

물리탐사방법은 종단면에 대한 연속적인 탐색이 용이한 장점이 있는 반면에 다른 부분들보다 상대적으로 취약한 부 분을 개략적으로 탐지할 수 있을 뿐이므로 탐지된 취약부분 이 어느 정도로 위험한지 판단하는 것은 곤란하다. 또한 취약 부분들이 존재해도 그 취약부분들이 침투류 흐름방향으로 연 속되어야 실질적인 누수의 위험이 있는 것으로 간주할 수 있 다. 일축종단면에 대한 탐사결과에서 상대적인 취약성이 심 각한 것으로 나타난 경우에도 침투류 흐름방향으로의 연속성 이 없기 때문에 취약성이 과장된다고 받아들여지고 있다.

각종 계측기를 제체 내외부에 직접 설치하여 상태를 감시 


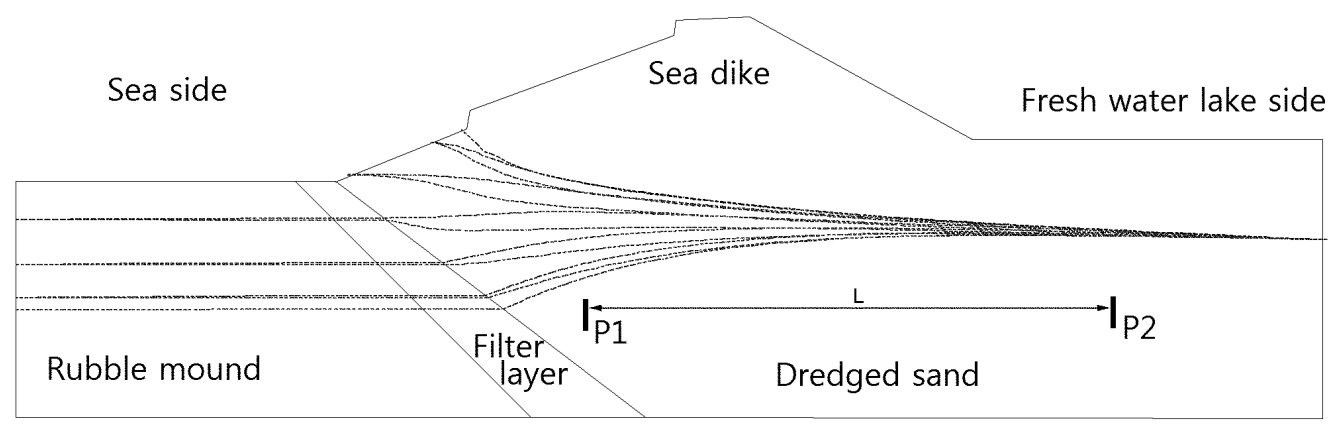

Fig. 1 The Schematic illustration of the measurement of seepage force (modified from the figure on Eam and Hoe, 2014)

하는 방법은 구조물의 길이가 긴 경우에는 제체의 종축방향 에 대한 탐지범위가 좁다는 단점이 있지만 적절하게 대표적 인 계측단면을 선정하면 제체 전 구간에 대한 평균적인 상태 의 변화 유무를 정밀하게 파악할 수 있다는 장점이 있다.

Eam et al. (2010a)은 공극수압계측에 의한 기존의 안정관 리 방법들이 조석현상의 영향에 의해서 유용성이 떨어지는 상황에서 보다 정확하게 감시할 수 있는 수두손실률기법을 개발하고 시화조력발전소 건설현장에 적용하였다. 방조제 제체 내부의 침투류는 $\operatorname{Eam}$ (2013)이 제시한 것과 같이 조석 현상의 영향을 받아서 해측에 가까운 부분에서는 침윤선의 변화가 크고 내측으로 멀어질수록 차수효과가 발휘되어서 변 화의 크기가 감소한다. 제체 내부에서 실측된 공극수압도 연 구결과와 동일한 파형을 나타내는데 이러한 특성으로 인해서 기존의 공극수압에 의한 안정관리방법을 적용하는 것이 곤란 하다. Eam et al. (2010b)은 준설해사로 성토된 방조제에서 측 정된 일부 공극수압자료를 수두손실률기법으로 분석하여 적 용성을 확인한 후에 방조제 전 구간에서 계측된 자료를 분석 하여 방조제의 안정성을 정량적으로 평가하였다 (Eam and Heo, 2014).

본 연구에서는 수두손실률에 의한 방조제 침투류 감시 기 법을 개선해서 침투경로길이에 대해서 정규화된 수두손실률 을 산출하고 제체의 횡단방향에 대한 구간별 차수상태를 평 가하는 방법을 제시하고 그 유용성을 확인하고자 한다.

\section{II. 재료 및 방법}

\section{1. 수두손실률의 정규화}

Eam et al. (2010a)은 유입부의 침투압이 주기적으로 변화 하는 해안가 물막이 제체의 효율적인 침투안정관리를 위해서 식 (1)과 같이 수두손실률을 정의하고 시화조력발전소 건설 현장에서 계측한 공극수압자료의 분석에 적용하였으며, 새
만금방조제에서 계측한 공극수압자료의 분석에도 적용하여 그 유용성을 확인하였다 (Eam et al, 2010b; Eam and Heo, 2014).

$$
\mathrm{a}=\frac{\Delta\left(\mathrm{H}_{\mathrm{P} 1}-\mathrm{H}_{\mathrm{P} 2}\right)}{\Delta\left(\mathrm{H}_{\mathrm{P} 1}\right)}
$$

여기서 $\mathrm{H}_{\mathrm{P} 1}$ : Fig.1 에서 침투류의 유입방향인 P1 공극수압 계에서 측정된 수두

$\mathrm{H}_{\mathrm{P} 2}$ : Fig.1 에서 침투류의 유출방향인 P2 공극수압 계에서 측정된 수두

$\Delta$ : 차분기호

이 연구에서는 Eam and Heo (2014)의 선행연구결과를 보 다 적극적으로 방조제 침투안정관리에 적용하기 위해서 수두 손실률을 방조제 횡단방향으로 구간별로 산출할 수 있도록 계측기를 신설하였다. 수두손실률 산출결과는 침투경로의 길이에 비례하는 경향이 있다 (Eam and Heo, 2014). 따라서 침투경로길이가 다른 조건에서 산출된 수두손실률의 대소를 비교하여 제체의 차수상태를 평가하는 것은 적절하지 않은 것으로 판단되어서 식 (2)와 같이 특정 구간에서 산출된 수두 손실률을 Fig. 1에 나타낸 구간경로길이 L로 나누어서 침투 경로 단위길이 당 수두손실률 $\left(\mathrm{a}_{\mathrm{n}}\right)$ 로 정규화하였다.

$$
\mathrm{a}_{\mathrm{n}}=\frac{\mathrm{a}}{\mathrm{L}}
$$

\section{여기서 a : 특정 유입부와 유출부에서 산출된 수두손실률} $\mathrm{L}$ : 유입부와 유출부 사이의 침투경로길이

\section{2. 해석자료}

새만금 4 호 방조제의 끝막이 구간의 차수상태를 정밀하게 


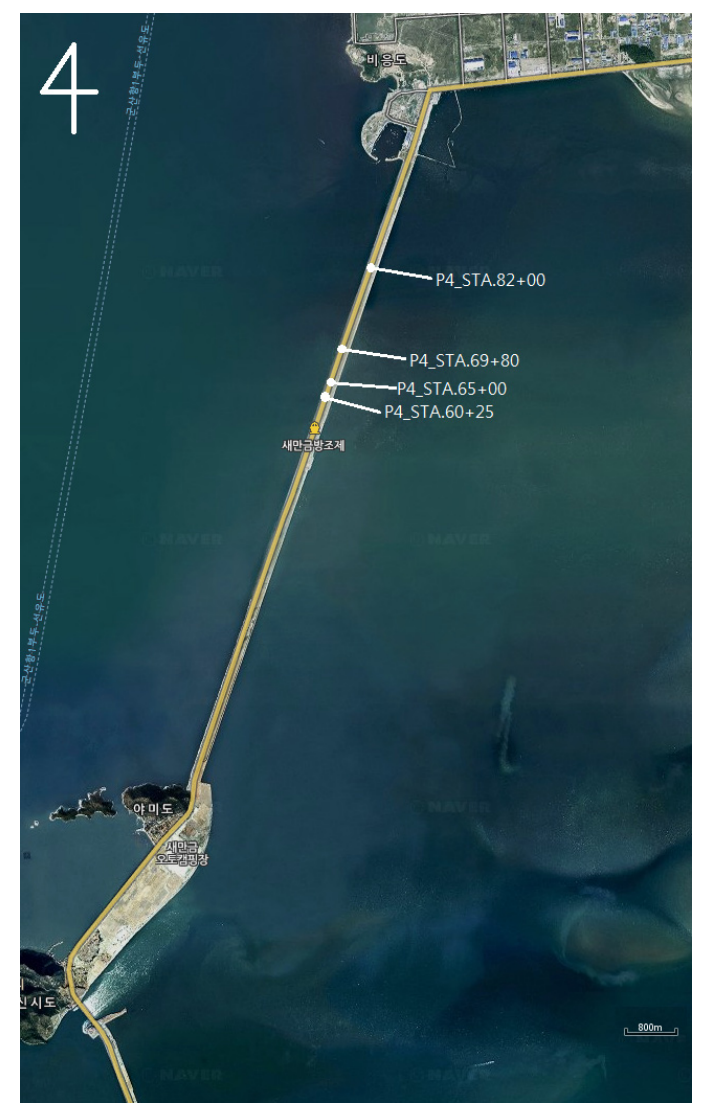

Fig. 2 The position of measurement section on Saemangum sea dike

평가하기 위해서 Fig. 2 와 같이 4 단면 (No. $60+25$, No. $65+00$, No.69+80, No.82+00)을 선정하여 계측기를 매설하였다. 계 측기 매설 위치를 선정하는 과정에서 수두손실률을 이용해서 제체의 상태를 평가하는 것으로 계획을 수립하고 이러한 목 적에 적합하도록 바닥보호공층의 일정한 깊이와준설해사 성 토체의 일정한 깊이에 해측으로부터 내측으로 4 열의 공극수 압계를 매설하였다.

Fig. 3(a) Fig. 3(d)는 각 단면의 계측기 설치 위치를 나타 낸 것이다. 1 열은 해측에 인접해 있고 $2,3,4$ 열은 침투류의 경 로상에 있다. 2 열에서 측정되는 공극수압을 P2로 하고 해측 조위를 P1으로 해서 수두손실률을 산정하면 제체 횡단면상 에서 가장 왼쪽의 해측면으로부터 2 열까지의 제체의 평균적 인 차수상태를 나타내게 된다. 4 열에서 측정된 공극수압과 해 측 조위로 수두손실률을 구하면 역시 제체의 해측면으로부터 내측에 가까운 4 열까지의 평균적인 차수상태를 나타내게 된 다. 각 단면별로 8 개의 공극수압계를 매설하여 총 32 개의 공 극수압계에 의한 끝막이 구간 실시간 계측시스템을 구현하 였다.
Fig. 4(a) (e)는 해측조위와 P4_STA.69+80 계측단면에 매설된 P-1, P-3, P-5, P-7 계측기에서 측정된 공극수두를 각 각 나타낸 것이다. 해측 조위는 해운항만청에서 운영하고 있 는 새만금방조제 인근의 위도 조위 관측소에서 측정한 자료 를 사용하였다. 2011년 9월 9일부터 10월 24일까지 계측한 자료를 분석에 이용하였다.

측정된 공극수압은 모두 해수면 기준 수두로 변환하여 나 타내었다. 해측조위는 대략 $\mathrm{EL} 0 \mathrm{~m}$ 을 기준으로 등락을 반복 하고 내부인 호측 수위는 관리수위인 EL-1.5 m를 유지하고 있으므로 각 계측기에서 측정된 공극수두의 평균값은 해측은 $\mathrm{EL} 0 \mathrm{~m}$ 부근에서 내측에 가까워질수록 EL-1.5 m를 향해서 하강해야 한다. P-1의 평균값은 EL $0 \mathrm{~m}$ 에 근접하게 나타났 다. P-3의 계측값은 9 월 30 일을 기준으로 전반부는 EL $0 \mathrm{~m}$ 부 근에서 평균값이 나타나지만 후반부에서는 더 높은 값을 나 타내어서 계측기의 매설심도가 변경되었음을 알 수 있다. 계 측기가 20 40 cm 범위에서 침강한 것으로 판단된다. P-5 계 측기는 평균값이 EL $0 \mathrm{~m}$ 보다 크게 나타났으므로 당초부터 매설깊이 산정에 오류가 있었음을 나타낸다. 또한 9 월 30일 전후에 계측기가 약간 상승하였음을 알 수 있다. P-7은 조석 의 영향이 상당히 감소해서 진폭이 작게 나타났으며 평균값 이 EL-0.8 m 부근에서 형성되었으므로 정상적인 경향을 나 타내고 있다. 수두손실률은 유입부의 수두와 유출부의 수두 사이의 차수효율을 평가하는 것이므로 이와 같이 계측기의 매 설심도가 잘못 산정된 경우에도 그 영향을 받지 않는 장점이 있다.

\section{III. 결과 및 고찰}

\section{1. 구간별 수두손실률 해석}

Fig. 5 Fig. 8은 구간해석의 과정을 상술하기 위해서 임의 로 선정한 P4_STA.69+80 단면에서 Fig. 3(c)의 아래쪽 침투 경로상에 놓여있는 P-1-> P-3 -> P-5 -> P-7 의 해석과정을 나 타낸 것이다. 1 열에서 측정된 공극수압과 해측 조위로부터 계 산한 수두손실률은 제체의 해측면 끝으로부터 1 열까지의 구 간해석이라고 할 수 있다. 해석결과 수두손실률이 Fig. 5(a)에 나타난 것과 같이 0.1775 이므로 해측 조위에 의한 침투압을 $100 \%$ 라고 할 때 Fig. 5(b)에 나타낸 절차에 따라서 전체의 $82.25 \%$ 만이 1 열까지 도달한다고 할 수 있다.

해측 조위 대신에 1 열에서 측정된 공극수두를 유입부의 수 두 P1 으로 하고 2열에서 측정된 공극수두를 유출부의 수두 P2 로 하면 1열에서 2열까지의 구간해석이 된다. Fig. 4(c)에 나타낸 P-3의 계측결과에서 9월 30 일을 전후로 공극수두의 
Pore water pressure sensor

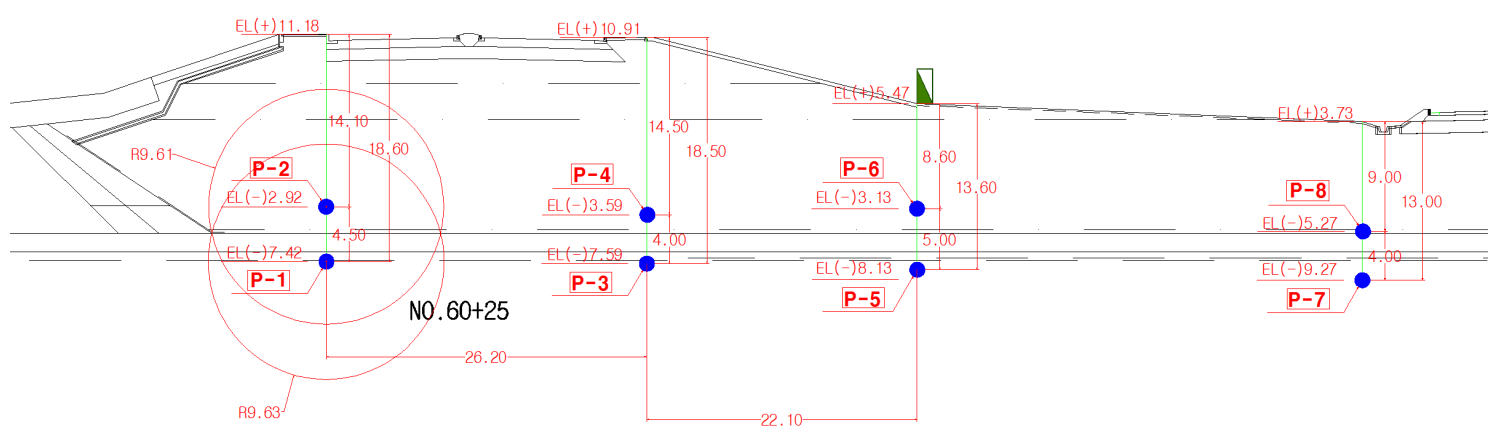

(a) The cross section of P4_STA.60+25

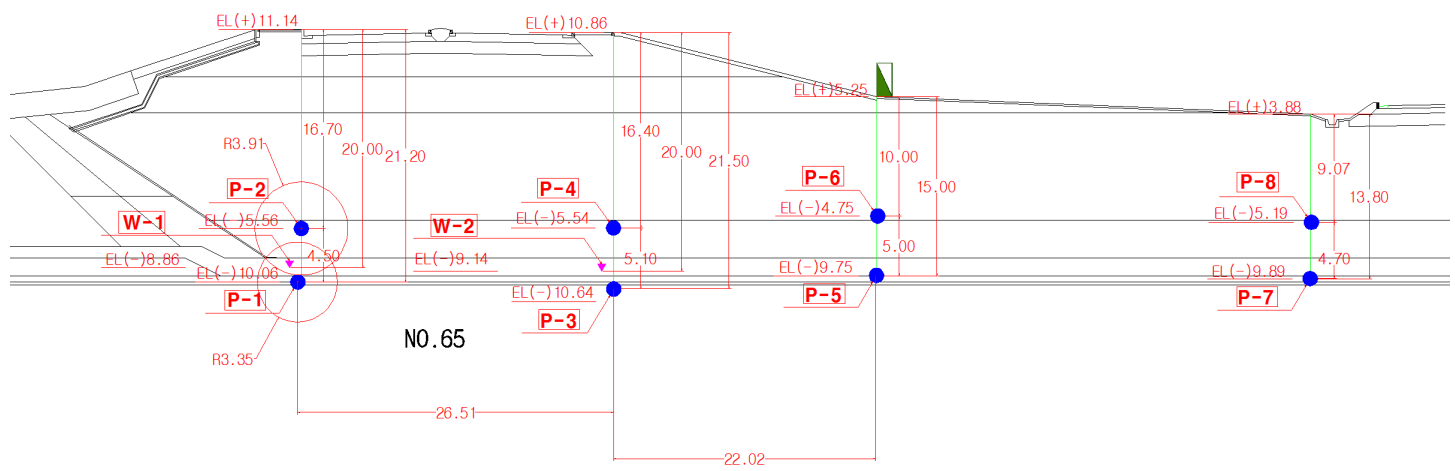

(b) The cross section of P4_STA.65+00

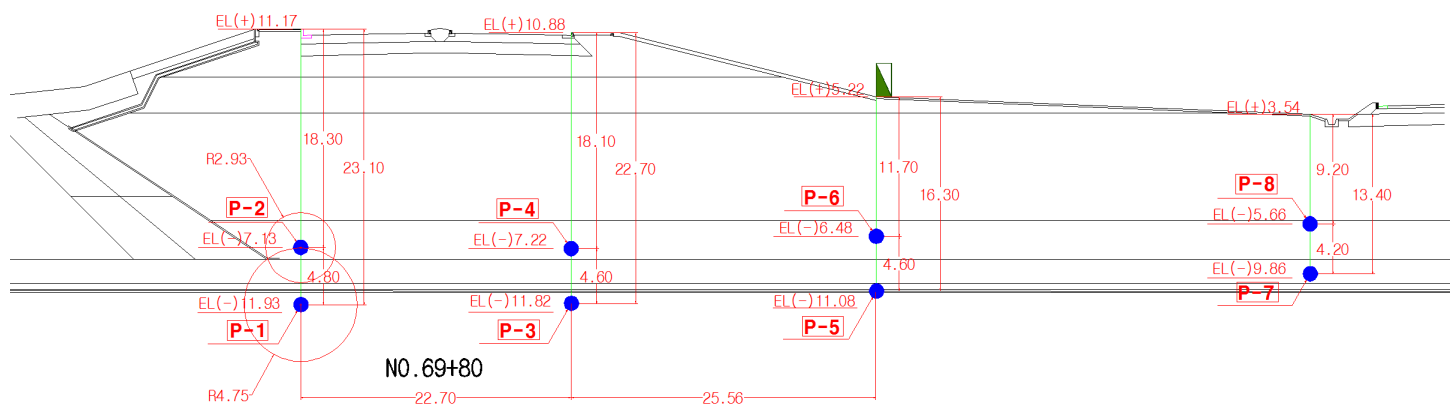

(c) The cross section of P4_STA.69+80

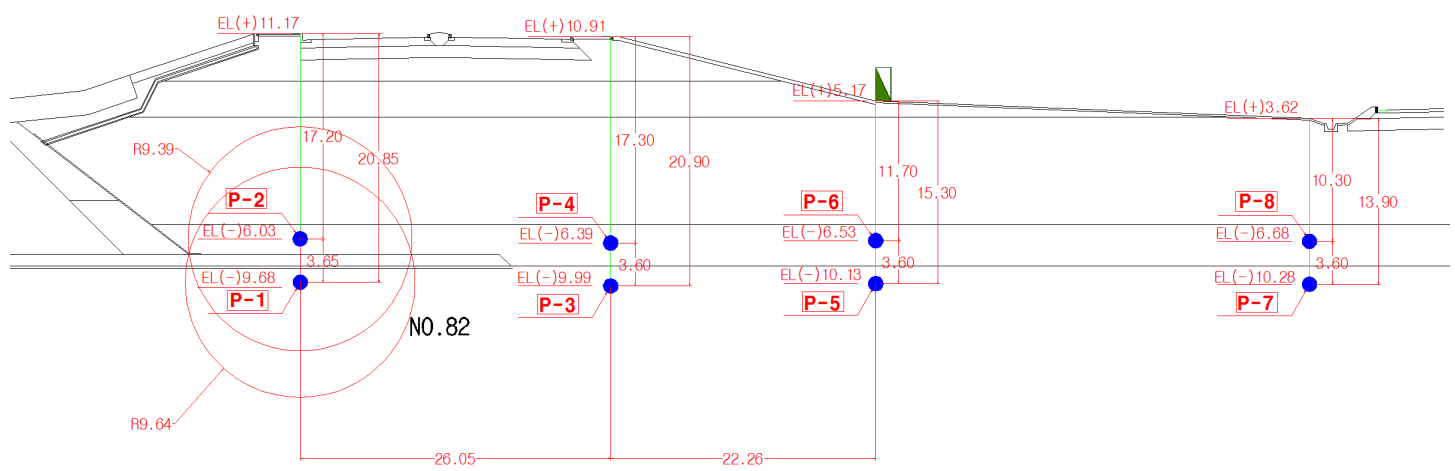

(d) The cross section of P4_STA.82+00

Fig. 3 Schematic illustration of Pore water pressure sensor installation profile 


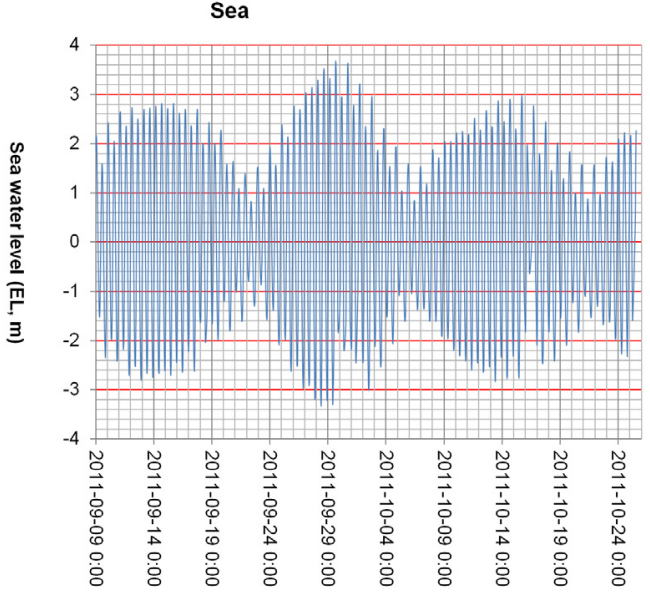

(a) The measured sea water levels

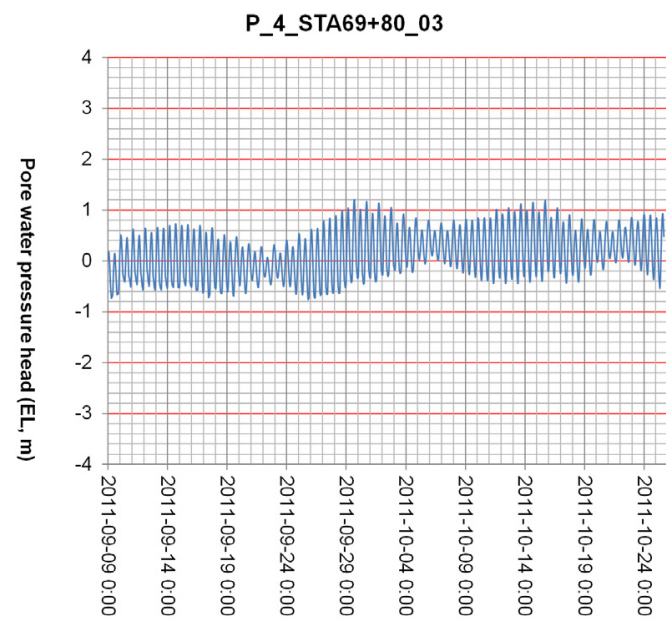

(c) The measured pore water pressures at sensor of $\mathrm{P}-3$ on P4_STA.69+80 section

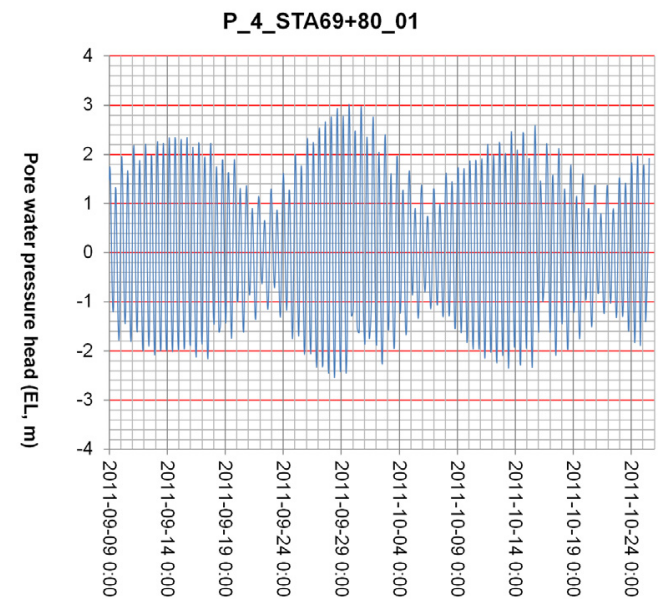

(b) The measured pore water pressures at sensor of $\mathrm{P}-1$ on P4_STA.69+80 section

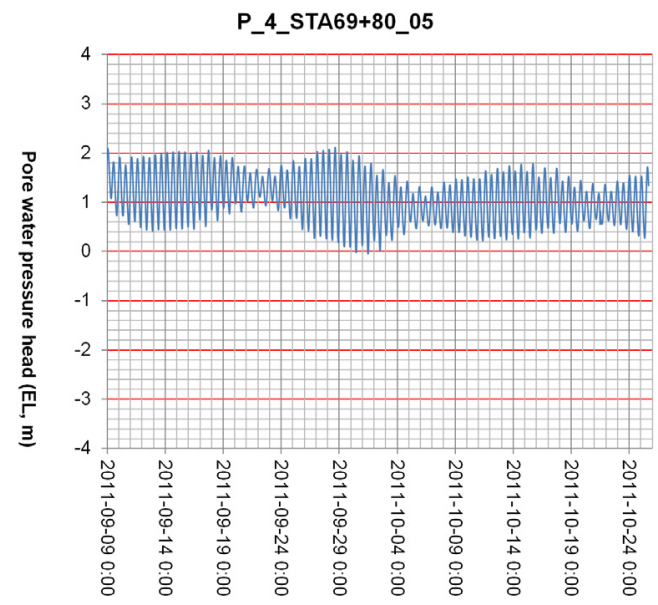

(d) The measured pore water pressures at sensor of $\mathrm{P}-5$ on P4_STA.69+80 section

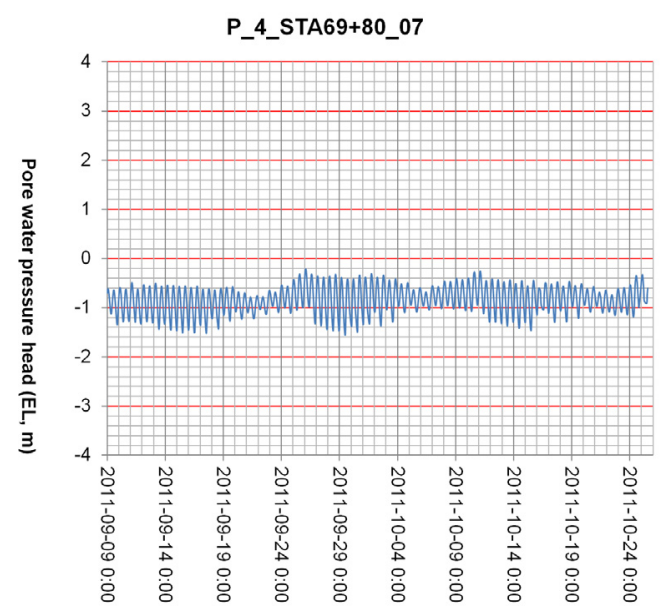

(e) The measured pore water pressures at sensor of P-7 on P4_STA.69+80 section

Fig. 4 Samples of the measured pore water pressure heads 
2011-09-09 2011-10-25

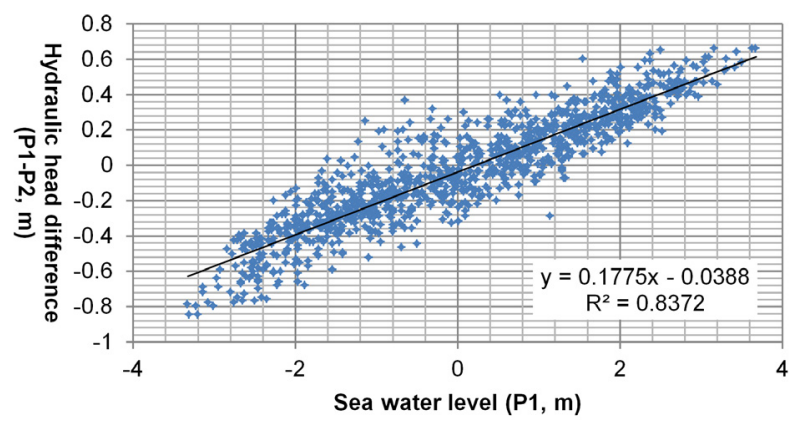

(a) The hydraulic head loss graph on the first segment of seepage path

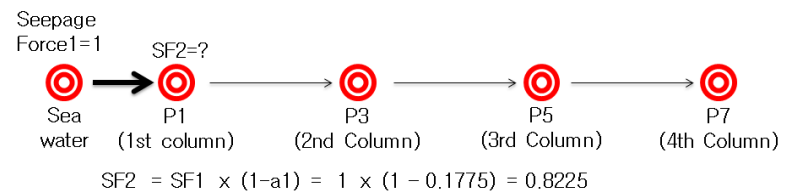

(b) The estimation of the seepage force reduced according to hydraulic head loss rate on first segment of seepage path

Fig. 5 The analysis on first segment of seepage path of the measurement cross section of P4_STA.69+80

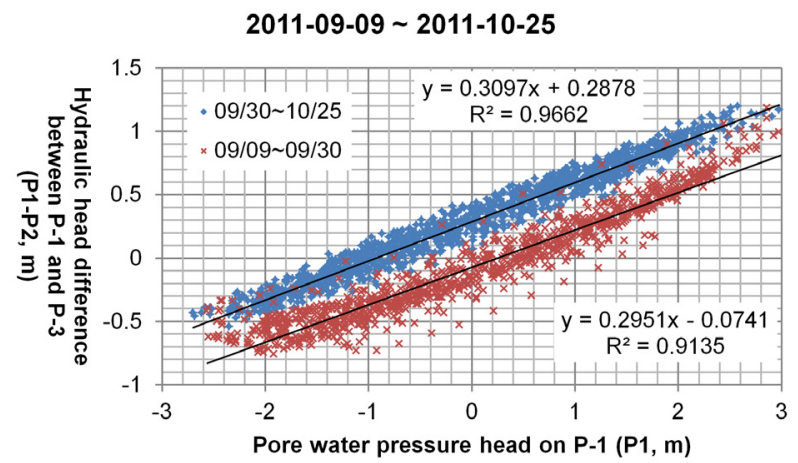

(a) The hydraulic head loss graph on the second segment of seepage path

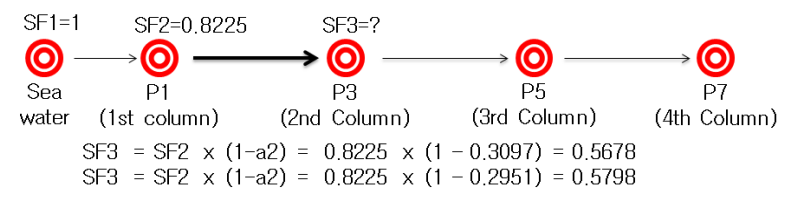

(b) The estimation of the seepage force reduced according to hydraulic head loss rate on second segment of seepage path

Fig. 6 The analysis on second segment of seepage path of the measurement cross section of P4_STA.69+80

평균값이 변동되었기 때문에 수두손실그래프도 Fig. 6(a)에 이원화된 두 가지 형상으로 나타났다. 수두손실률은 0.3097
2011-09-09 2011-10-25

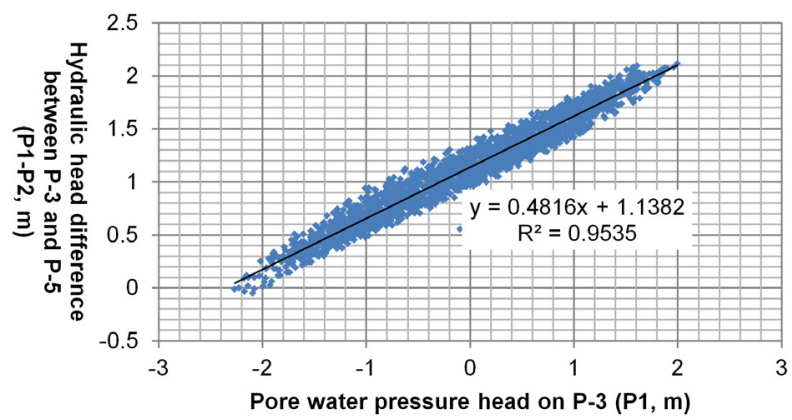

(a) The hydraulic head loss graph on the third segment of seepage path

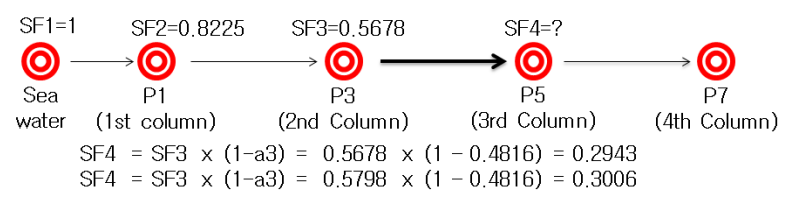

(b) The estimation of the seepage force reduced according to hydraulic head loss rate on third segment of seepage path

Fig. 7 The analysis on third segment of seepage path of the measurement cross section of P4_STA.69+80

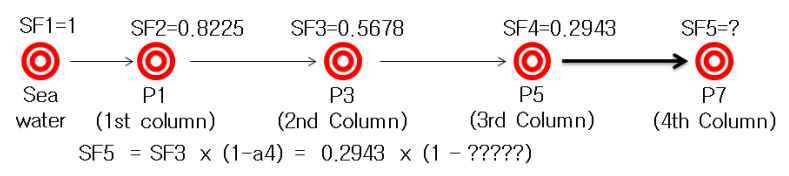

Fig. 8 The estimation of the seepage force reduced according to hydraulic head loss rate on fourth segment of seepage path of the measurement cross section of P4_STA.69+80

과 0.2951 로 그 변화가 크지 않고 결정계수도 1 에 가까운 큰 값을 나타내고 있으므로 침투경로상에 제체의 상태가 변한 것이 아니고 계측기의 매설깊이가 변경된 것으로 판단되었 다. 따라서 이후부터 두 가지 경우에 대해서 침투압의 감소량 을 산정하였다. 해석결과 나타난수두손실률 0.3097 과 0.2951 에 의해서 감소되어 2열에 도달하는 침투압은 Fig. 6(b)에 나 타낸 것과 같이 각각 $56.78 \%, 57.98 \%$ 이다.

마찬가지로 2 열에서 측정된 공극수두를 유입부의 수두 P1 으로 하고 3 열에서 측정된 공극수두를 유출부의 수두 P2 로 하여 2열과 3열 사이의 구간해석을 하면 수두손실률이 Fig. 7 (a)와 같이 0.4816 이므로 2 열의 침투압을 $100 \%$ 라 하면 3 열에 도달하는 침투압은 $51.84 \%$ 가 되며 누적되어 감소된 해 측 조위 침투압은 Fig. 7(b)와 같이 각각 $29.43 \%$ 및 $30.06 \%$ 가 도달한다.

4열은 진폭이 작고 내측에 인접해 있어서 내부 호측 수위 


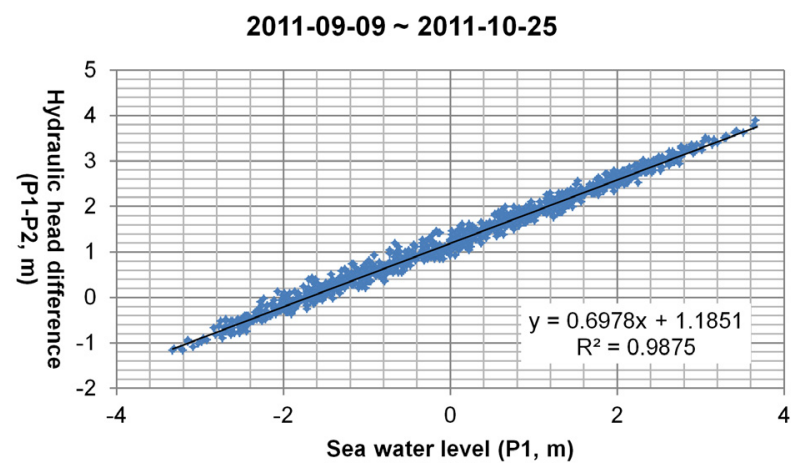

(a) Hydraulic head loss graph between sea water and P-5

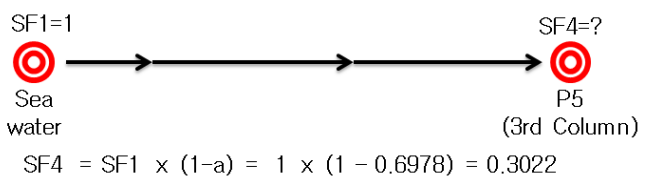

(b) Seepage force reduced through path from sea water to $\mathrm{P}-5$

Fig. 9 The estimation of the seepage force reduced according to hydraulic head loss rate on $\mathrm{P}-5$ of the measurement cross section of P4_STA.69+80

의 영향을 받아서 수두손실율 해석이 원활하게 수행되지 않 았다. 해측 수위가 내측수위보다 높아서 침투류가 해측에서 내측으로 흐르는 경우와 해측수위가 내측보다 낮아서 침투류 가 내측에서 해측으로 흐르는 경우가 모두 포함되어 있기 때 문으로 판단된다.

\section{2. 수두손실률에 의한 방조제 모니터링 시스템 검증}

해측 조위를 유입부의 수두로 하고 3 열에 있는 P-5에서 측 정된 공극수두를 유출부의 수두로 설정하고 해석하여 얻은 기존의 수두손실률을 Fig. 9(a)에 나타내었다. 제체의 해측 끝 으로부터 3 열까지의 평균적인 차수상태를 나타내는 수두손 실률로써 0.6978 이므로 해측조위에 의한 침투압은 Fig. 9(b) 와 같이 3 열에 $30.22 \%$ 가 도달한다고 할 수 있다.

구간별 해석을 3 열까지 누적한 결과와 3 열의 공극수두와 해측 조위를 기준으로 해석한 결과를 서로 비교하면 해석기 법 및 하드웨어 등 전체 시스템의 신뢰성을 검증할 수 있다. Fig. 10 에 의하면 수두손실그래프가 변동된 P-3의 자료에서 안정적으로 나타난 후반부 9/30 10/25 자료를 적용하면 $3 \%$ 의 차이가 있을 뿐이며 전반부 9/9 9/29 자료를 적용하면 더 욱 작은 $1 \%$ 의 오차만 발생한다. 이와 같이 작은 오차가 나타 난다는 것은 계측기의 Calibration, 각 계측시각의 동기화 등 전체 시스템이 정확하게 작동하고 있으며 수두손실률에 의한 해석기법도 신뢰성이 있다는 것을 의미한다.

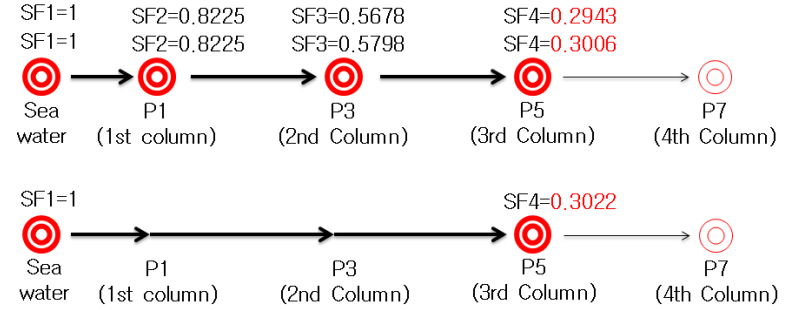

Fig. 10 The comparison between the seepage force estimated through segments and the seepage force estimated based on sea water level

\section{3. 수두손실률의 정규화에 의한 제체의 차수상태평가}

계측단면 4 개 전체에 대해서 해측조위를 유입부의 수두 P1 으로 설정하고 해석한 수두손실률을 Fig. 11(a)에 나타내었 다. 제체의 해측 끝으로부터 1 열까지의 수두손실률은 $0.2 \sim 0.66$ 의 범위에 있다. 2 열에서는 $0.44 ~ 0.93$ 사이에 있고 3 열에서는 0.63 0.99에 있으며 4열에서는 0.86 이상이다. 해측 조위를 기준으로 하는 경우에는 이와 같이 제체의 횡단폭이 증가할 수록 차수효과도 커지는 것으로 나타났다. 그러나 이러한 결 과는 제체의 내측에서 양호한 차수상태를 판단할 수 있는 정 량적인 지표가 되기는 하지만 침투류의 경로가 길어질수록 수두손실도 커지는 당연한 현상이다. 제체의 횡단면 상의 특 정 부분이 다른 부분들보다 느슨한 경우에도 전반적으로 Fig. 11(a)와같은 패턴에서 크게 벗어나지는 않을 것이다. 이와같 은 요인을 제거하기 위해서 구간별 해석을 한 결과를 Fig. 11(b)에 나타내었다. 1열의 구간해석에서 유입부의 수두 P1 은 해측 조위이므로 Fig. 11(a)의 1열과 동일한 값을 다시 나 타내었다. 2 열과 3 열은 구간해석결과를 나타낸 것이고 내부 호측 수위변동의 영향을 많이 받은 4 열은 제외하였다. 각 구 간별로 구분하여 해석한 결과에서는 전반적으로 비슷한 범위 의 수두손실률을 나타내고 있으며 세부적으로는 2 열의 수두 손실률 최저값이 1 열이나 3 열보다 크고 1 열이 가장 작은 것으 로 나타났다. 각 구간별 침투경로는 3 열 4 열 사이가 가장 길 고 1열 2열, 2열 3열, 해측 1열 순으로 짧아진다.

이와 같이 침투경로가 다른 조건에서 얻은 수두손실률의 대소를 단순 비교하는 것은 적절하지 않으므로 각 구간별 침 투경로를 산정하고 각 구간별 수두손실률을 경로길이로 나누 어서 단위침투경로당 수두손실률로 정규화한 결과를 Fig. 11 (c)에 나타내었다. 1 열과 2 열 사이 및 2열과 3 열 사이의 침 투경로길이는 명확하게 파악할 수 있으나 1 열의 침투경로를 설정하는 것은 불확실한 요소들이 포함되어 있다. Fig. 3 에서 1 열들에 매설되어 있는 P-1 과 P-2 공극수압계들에 대해서는 1 차 사석단면과 준설해사 성토단면의 경계면까지의 거리를 


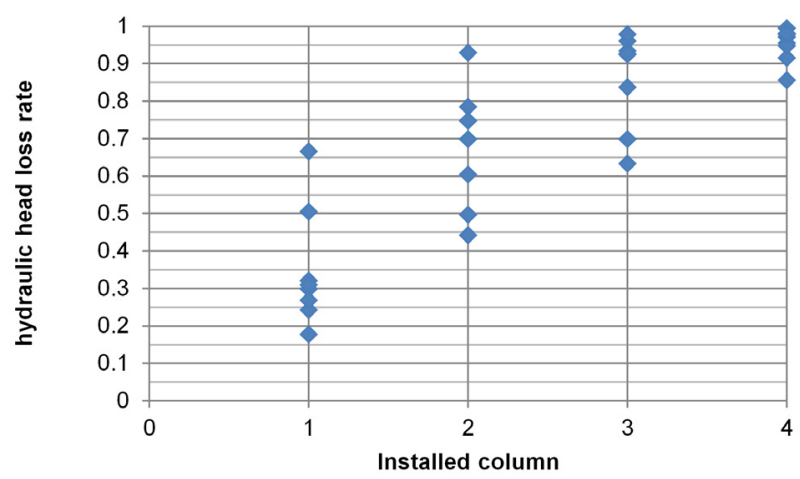

(a) Hydraulic head loss rates based on sea water level

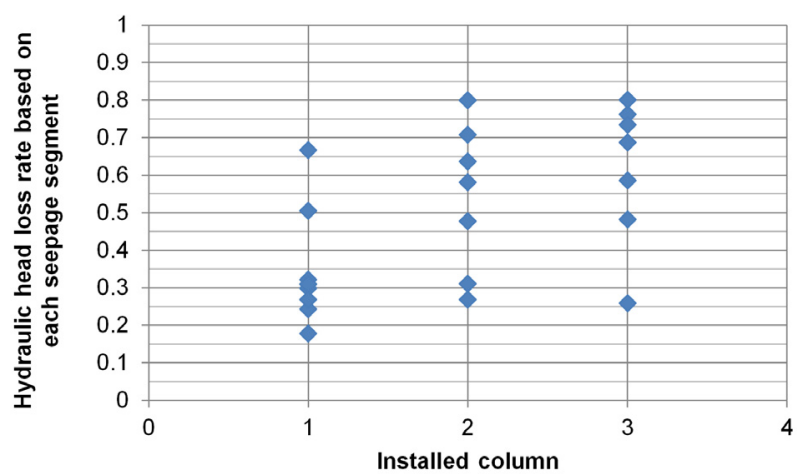

(b) Hydraulic head loss rates based on each seepage segment

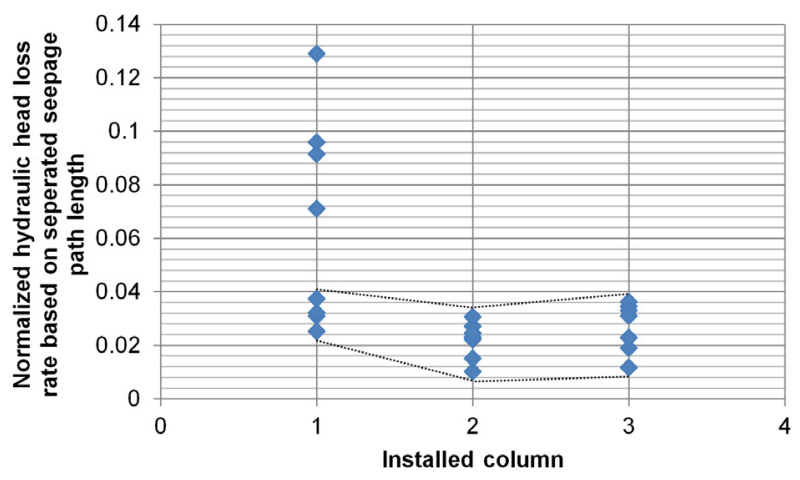

(c) Thy hydraulic head loss rates normalized by segment length

Fig. 11 The comparison of the hydraulic head loss rates between the normalized by segment length, the estimated based on segments, the estimated based on sea water level

침투 경로 길이로 설정하였다. 1 차 사석단면의 공극이 매우 크기 때문에 조석현상과 같이 약 3 시간 동안 최대 $4.2 \mathrm{~m}$ 정도 가 상승하거나 하강하는 경우에 1차사석단면을 통과하는 조 류의 느린 흐름이 받는 부하는 무시할 수 있을 정도로 작은 크 기이므로 두 단면의 경계면을 수두손실의 시작위치로 설정하 였다. 그러나 실제 시공과정에서 1 차사석단면에서 공극의 일 부가 보다 작은 입경의 사력이나 토사로 충진되었을 수도 있
고 바닥보호공의 1 열에 매설된 공극수압계 전방은 충진이 더 많이 되었을 수도 있고 반대로 세굴이 일어났을 수도 있기 때 문에 침투경로장 산정에 있어서 다른 구간에 비해서 상대적 으로 불확실한 요인들이 포함되어 있다. 이것이 1 열의 정규화 된 수두손실률의 분포 범위가 다른 열의 분포 범위보다 큰 요 인으로 생각된다. 정규화된 수두손실률에 의하면 제체는 해 측과 내측에 무관하게 전반적으로 고른 차수효과를 발휘하고 있으나 1열 2열 구간이 다른 부분들보다 미세하게나마 차수 효과가 낮게 나타났다. 일반적인 경향을 벗어나는 값들을 제 외한다면 정규화된 수두손실률의 평균값은 $0.024512 / \mathrm{m}$ 이 며 이것은 현재의 다짐상태인 준설해사 성토단면이 단위길이 당 약 $2.5 \%$ 의 효율로 침투류를 막고 있으므로 침투를 완전하 게 차단하기 위해서는 약 $41 \mathrm{~m}$ 의 횡단폭이 필요하다는 것을 의미하며 침투에 관한 한 새만금 방조제는 현재 충분한 횡단 폭을 확보하고 있는 것으로 판단된다. 이러한 결과는 조석현 상을 고려한 제체 내의 침투해석에 관한 기존의 연구결과 (Eam, 2013)와도 일치하는 것이다.

\section{IV. 결 론}

수두손실률에 의한 방조제 침투류 감시 기법을 개선해서 단위침투경로길이에 대해서 정규화된 수두손실률을 산출하 고 제체의 횡단방향에 대한 구간별 차수상태를 평가하는 방 법을 개발하고 실제 계측자료에 적용하여 다음과 같은 결과 를 얻었다.

(1) 방조제와 같이 투수성재료로 차수구조물을 축조할 경우 에 침투경로상에 일정한 간격으로 공극수압계를 매설하 여 계측을 수행하면 정규화된 수두손실률을 비교함으로 써 침투경로상의 각 구간별로 차수상태를 평가할 수 있다.

(2) 동일한 침투경로상에 계측기를 매설함으로써 구간별 해 석이 가능할 뿐만 아니라 전체계측시스템이 올바르게 작 동하고 있는지 여부를 검사할수 있는 조건도 구성이 된다.

(3) 정규화된 수두손실률을 이용해서 제체의 차수상태를 평 가한 결과 전체 횡단면상의 침투경로에 대해서 전반적으 로 균일한상태이며 조석의 차단에 충분한 단면폭을 확보 하고 있음을 확인할 수 있었다.

\section{REFERENCES}

1. Closson, D., and N. A. Karaki, 2014. Dikes stability monitoring versus sinkholes and subsidence, dead sea region, jordan, Ch. 10. In Land Applications of Radar Remote Sensing, ed. F. 
Holecz, P. Pasquali, N. Milisavljevic and D. Closson, : 281-307. InTech. under CC BY 3.0 License.

2. Eam, S. H. and G. Heo, 2014. Development of seepage monitoring and analysis method with the hydraulic head loss rate in sea dike. Journal of the Korean Society of Agricultural Engineers 56(6): 1-9 (in Korean).

3. Eam, S. H., 2013. The analysis of tidal effect on stress-strain behavior in the boundary surface of sea dike embankment. Journal of the Korean Society of Agricultural Engineers 55(2): 1-8 (in Korean).

4. Eam, S. H., B. Y. Kang, K. W. Kim, J. H. Koo, S. I. Kang, H. Y. Cha, J. H. Jung, J. H. Cho, and K. S. Kim, 2010a. Development of the seepage flow monitoring method by the hydraulic head loss rate. Journal of the Korean Geotechnical Society 26(5): 37-48 (in Korean).

5. Eam, S. H., C. Y. Yoon, S. P. Kim, and J. Heo, 2010 b. Development of the seepage flow monitoring method by the hydraulic head loss rate on sea dike. In KGJ Fall National Conference,: 60-68. Gyoenghi, Korea (in Korean).

6. Hanssen, R. F. and F. J. Van Leijen, 2008. Monitoring deformation of water defense structures using satellite radar interferometry. In 13th FIG Symposium on Deformation Measurement and Analysis: 1-7.

7. Kim, Y. J., I. K. Cho, H. H. Yong, and S. H. Song, 2013. Time-lapse inversion of 3D resistivity monitoring data. Jigu-Mulli-wa-Mulli-Tamsa 16(4): 217-224 (in Korean). 